\title{
Factors influencing troponin T concentration in patients with obstructive sleep apnea syndrome
}

\author{
Czynniki wpływające na stężenie troponiny T u pacjentów \\ z zespołem obturacyjnego bezdechu sennego
}

\author{
Marcin Urbańczuk ${ }^{1}$, Paweł Kiciński ${ }^{1}$, Andrzej Dybała ${ }^{2}$, Wojciech Myśliński ${ }^{2}$, \\ Jerzy Mosiewicz ${ }^{2}$, Andrzej Jaroszyński ${ }^{1,3}$ \\ ${ }^{1}$ Department of Family Medicine, Medical University of Lublin, Poland \\ ${ }^{2}$ Department of Internal Diseases, Medical University of Lublin, Poland \\ ${ }^{3}$ The Jan Kochanowski University, Faculty of Medicine and Health Sciences, Kielce, Poland
}

\section{Abstract}

Introduction. Obstructive sleep apnea syndrome (OSAS) is strongly associated with adverse cardiovascular outcomes, however the relation between OSAS severity and troponin $\mathrm{T}(\mathrm{TnT})$ remain unclear.

Material and methods. Diagnosis and assessment of OSAS severity was based on non-supervised, overnight screening polysomnography (PSG) performed without an adaptation night. The study group consisted of 72 patients diagnosed with OSAS (including 31 with mild, 10 with moderate and 31 patients with severe OSAS), whereas the control group contained 16 individuals. PSG was performed with equipment fulfilling the criteria of type III diagnostic devices according to the American Academy of Sleep Medicine.

Results. Revealed significant differences in troponin T levels between patients with severe OSAS and controls $(p=0.02)$ as well as in patients with severe and with mild OSAS ( $p=0.04)$. The factors substantially affecting TnT concentrations were found to be apnea-hypopnea index (AHI), apnea index ( $\mathrm{Al})$, hypopnea index ( $\mathrm{HI}$ ) and minimum nocturnal saturation.

Conclusions. The relationship between sleep apnea syndrome and the level of serum TnT confirms that OSAS predisposes to myocardial damage in a manner dependent on the severity of sleep apnea. The increase in troponin level is mainly associated with $\mathrm{AHI}$ and minimum nocturnal saturation. This suggests that early treatment of OSAS patients may protect against myocardial injury.

Key words: troponin T, obstructive sleep apnea, apnea-hypopnea index, myocardial injury, polysomnography

Folia Cardiologica 2016; 11, 5: 372-376

\section{Introduction}

Obstructive sleep apnea syndrome (OSAS) is a condition caused by episodes of breathing disorders in the form of short-term pauses in breathing during sleep. Apnea is defined as cessation of respiration for 10 seconds or more that results in a reduction of airflow to $90 \%$ below normal caused by limited airflow at the level of the pharynx associated with enhanced work of respiratory muscles. A sum of all apneas and hypopneas per one hour of sleep, i.e. the apnea-hypopnea index (AHI), is a key criterion for the diagnosis and classification of OSAS [1]. According to AHI values, OSAS is divided into mild, moderate and severe. Obstructive sleep apnea affects about $9-26 \%$ of the adult

Address of correspondence: lek. Marcin Urbańczuk, Katedra i Zakład Medycyny Rodzinnej, SPSK nr 1, ul. M. Langiewicza 6A, 20-032 Lublin, e-mail: marcin_urbanczuk@wp.pl 
population and even $70 \%$ of individuals $>60$ years of age $[2,3]$. OSAS is considered one of the risk factors of such diseases as arterial hypertension, metabolic syndrome, heart failure or coronary disease [4].

Cardiac troponins are specific markers mainly used to diagnose acute coronary syndromes. Their increases are observed in myocardial damage associated with ischemia, trauma or inflammation. Moreover, cardiac troponins increase during pulmonary and renal diseases, cerebral stroke or chronic circulatory failure. Even slight elevations in troponins are likely to be associated with subclinical myocardial damage [5]. The damage is directly proportional to their increase. Regardless the underlying reason of troponin $\mathrm{T}(\mathrm{TnT})$ elevation, its increase is considered strong and independent predictor of cardiac injury and worse prognosis [6]. Only a few studies have assessed relation between the troponin level and severity of sleep apnea and their findings are often inconsistent [7].

The aim of the study was to assess the parameters affecting TnT levels in patients with OSAS.

\section{Material and methods}

An observational, cross-sectional study was undertaken. Its design was approved by the Bioethics Committee of the Medical University of Lublin; all the patients enrolled in the study gave their written informed consent for participation.

\section{Patients}

The study encompassed individuals referred to the sleep laboratory of the University Hospital in Lublin due to suspected breathing disorders during sleep.

The exclusion criteria were history of ischemic heart disease, prior myocardial infarction, chronic heart failure, chronic obstructive lung disease, chronic kidney diseases - stages III-V, acute and chronic liver damage, acute infections and PSG-detected breathing disorders other than OSAS. The control group included individuals subjected to PSG, which excluded sleep breathing disorders.

\section{Polysomnography}

Diagnosis and assessment of OSAS severity was based on non-supervised, overnight screening PSG performed with an adaptation night. SleepDoc Porti 6 and Porti 8 systems (Dr. Fenyves und Gut Deutschland $\mathrm{GmbH}$ ) were used fulfilling the criteria of type III diagnostic devices according to the American Academy of Sleep Medicine (AASM). The following parameters were recorded and analyzed: the apnea-hypopnea index (AHI) defined as the number of apneas and hypopneas per one hour of examination, apnea index ( $\mathrm{Al}$ ) and hypopnea index $(\mathrm{HI})$ reflecting the number of apneas and hypopneas per one hour of examination, respectively, respiratory distress time (RDT), i.e. total duration of apneas and hypopneas during the entire examination in minutes, respiratory distress time index (RDTI), i.e. duration of apneas and hypopneas over one hour of examination, mean and minimum saturation $\left(\mathrm{SpO}_{2}\right)$ during the examination, and time of hypoxia/hypoxemia (t90), defined as the percentage of examination time with saturation below $90 \%$.

According to the AASM recommendations, the following criteria for OSAS diagnosis were accepted: $A H I \geq 15 / h$ or $A H I \geq 5 / h$ accompanied by typical clinical symptoms.

Three degrees of OSAS severity were distinguished: mild with $\mathrm{AHI} \geq 5 / \mathrm{h}$ and $<15 / \mathrm{h}$, with accompanying clinical symptoms, moderate with $\mathrm{AHI} \geq 15 / \mathrm{h}$ and $<30 / \mathrm{h}$ and severe with $A H I \geq 30 / h$.

\section{Biochemical measurements}

The material for the study was the peripheral blood obtained from the ulnar vein. Blood samples were collected after an 8-12 hours overnight fast between 8:00 and 10:00 am into clot tubes in volumes of $7 \mathrm{ml}$. Troponin T concentrations were determined using an automated immunochemiluminescence analyzer.

\section{Statistical analysis}

STATISTICA 10 PL software (Statsoft Inc., USA) was used for statistical analysis of data. $P<0.05$ was considered statistically significant. For descriptive statistics, the mean and standard deviation (SD) were used as a measure of dispersion. Normality of distribution was checked with the Shapiro-Wilk W test. The Student's t-test was applied to check the significance of differences for two independent samples (normal distribution) when homogeneity of variance was confirmed (the Levene's test). In cases of non-homogenous variance or variables of non-normal distribution, the Mann-Whitney $U$ test was used. Intergroup differences in qualitative variables were analyzed using the $x^{2}$ test. To compare the differences in dependent variables in more than two groups, univariate and multivariate ANOVA tests were applied. The Tukey's test was employed for detailed identification of statistically different groups. The strength and direction of correlations between two variables was examined using the Pearson linear correlation coefficient (for normal distribution of variables) or the Spearman rank correlation test (when the distribution was not normal).

\section{Results}

The control group consisted of 16 subjects without breathing disorders during sleep whereas the study group encompassed 72 patients with confirmed OSAS (including 31 with mild, 10 with moderate and 31 patients with severe OSAS). Demographic characteristics and basic clinical data of the control and study groups were listed in Table 1; biochemical findings were presented in Table 2. 
Table 1. Demographical and clinical characteristics of patients

\begin{tabular}{|c|c|c|c|c|}
\hline Parameter & $\begin{array}{l}\text { Control group } \\
\quad(n=16)\end{array}$ & $\begin{array}{l}\text { Mild OSAS } \\
\quad(n=31)\end{array}$ & $\begin{array}{c}\text { Moderate } \\
\text { OSAS }(n=10)\end{array}$ & $\begin{array}{l}\text { Severe OSAS } \\
\quad(n=30)\end{array}$ \\
\hline Age (yrs) & $50.2 \pm 14.8$ & $52.7 \pm 12.3$ & $56.8 \pm 8.8$ & $54.3 \pm 12$ \\
\hline No. of males [\%] & 56 & 60 & 93 & 82 \\
\hline $\mathrm{AHI}\left[\mathrm{h}^{-1}\right]$ & $2.1 \pm 1.7$ & $10.5 \pm 5.6$ & $21.7 \pm 5.4$ & $53.6 \pm 16.8$ \\
\hline Al $\left[h^{-1}\right]$ & $0.5 \pm 0.6$ & $4.4 \pm 2.9$ & $12.8 \pm 6.4$ & $41.5 \pm 19.9$ \\
\hline $\mathrm{HI}\left[\mathrm{h}^{-1}\right]$ & $1.6 \pm 1.5$ & $6 \pm 4.6$ & $8.9 \pm 4.4$ & $11.9 \pm 9.5$ \\
\hline RDT [min] & $4.6 \pm 5.3$ & $21.6 \pm 9.1$ & $51 \pm 22.2$ & $141.3 \pm 64.2$ \\
\hline RDTI [min/h] & $1.7 \pm 4.9$ & $3.4 \pm 1.9$ & $8.6 \pm 4.5$ & $24 \pm 9.9$ \\
\hline Minimal $\mathrm{SpO}_{2}[\%]$ & $85.9 \pm 4.5$ & $81.2 \pm 4.8$ & $77 \pm 7.2$ & $66.7 \pm 12.7$ \\
\hline Mean $\mathrm{SpO}_{2}[\%]$ & $92.7 \pm 1.6$ & $91.6 \pm 1.8$ & $91.3 \pm 2.1$ & $88.7 \pm 3.9$ \\
\hline Time of hypoxemia [\%] & $1.6 \pm 3.3$ & $6.3 \pm 13.8$ & $11.5 \pm 17.1$ & $32.2 \pm 24.4$ \\
\hline Arterial hypertension [\%] & 78 & 64 & 79 & 79 \\
\hline Type 2 diabetes [\%] & 11 & 33 & 54 & 21 \\
\hline
\end{tabular}

OSAS - obstructive sleep apnea syndrome; AHI - apnea-hypopnea index; Al - apnea index; $\mathrm{HI}$ - hypopnea index; RDT - respiratory distress time; $\mathrm{RDTI}$ - respiratory distress time index; $\mathrm{SpO}{ }_{2}$ - saturation

Table 2. Biochemical characteristics of patients

\begin{tabular}{lcccc} 
Parameter & $\begin{array}{c}\text { Control group } \\
(\mathrm{n}=16)\end{array}$ & $\begin{array}{c}\text { Mild OSAS } \\
(\mathrm{n}=31)\end{array}$ & $\begin{array}{c}\text { Moderate OSAS } \\
(\mathrm{n}=10)\end{array}$ & $\begin{array}{c}\text { Severe OSAS } \\
(\mathrm{n}=30)\end{array}$ \\
\hline Hemoglobin $[\mathrm{g} / \mathrm{dL}]$ & $14.3 \pm 1.65$ & $14.5 \pm 1.18$ & $14.6 \pm 1.37$ & $14.7 \pm 1.26$ \\
Creatinine $[\mathrm{mg} / \mathrm{dL}]$ & $0.81 \pm 0.16$ & $0.82 \pm 0.17$ & $0.86 \pm 0.17$ & $0.87 \pm 0.18$ \\
Uric acid $[\mathrm{mg} / \mathrm{dL}]$ & $6.13 \pm 1.24$ & $6.47 \pm 1.24$ & $6.23 \pm 0.83$ & $6.46 \pm 1.49$ \\
C-reactive protein $[\mathrm{mg} / \mathrm{L}]$ & $4.87 \pm 9.07$ & $2.85 \pm 3.67$ & $2.47 \pm 2.37$ & $4.7 \pm 7.5$ \\
Potassium $[\mathrm{mmol} / \mathrm{L}]$ & $4.33 \pm 0.36$ & $4.23 \pm 0.28$ & $4.36 \pm 0.34$ & $4.32 \pm 0.36$ \\
Thyreotropin $[\mu \mathrm{lU} / \mathrm{mL}]$ & $1.54 \pm 0.78$ & $1.91 \pm 3.34$ & $1.8 \pm 1.77$ & $2.07 \pm 4.44$ \\
Troponin T $[\mathrm{ng} / \mathrm{mL}]$ & $0.005 \pm 0.004$ & $0.006 \pm 0.004$ & $0.0057 \pm 0.004$ & $0.01 \pm 0.001$
\end{tabular}

OSAS - obstructive sleep apnea syndrome

One-way ANOVA demonstrated significant differences in TnT levels ( $p=0.02$ ). The Tukey's test for multiple comparisons revealed significant differences in TnT levels between patients with severe OSAS and controls $(p=0.02)$ as well as between patients with severe OSAS and mild OSAS ( $p=0.04$ ) (Fig. 1).

Considering inter-subgroup differences in gender structure, bivariate ANOVA was applied; the results did not show any significant influence of gender on TnT concentration.

Statistically significant correlations were found between TnT concentration and AHI, Al, HI, RDT, RDTI, and minimum $\mathrm{SpO}_{2}$ (Table 3).

\section{Discussion}

OSAS adversely affects the functioning of the myocardium and leads to its remodeling. Higher degrees of OSAS severity have been demonstrated to be associated with increased morbidity and mortality due to cardiovascular

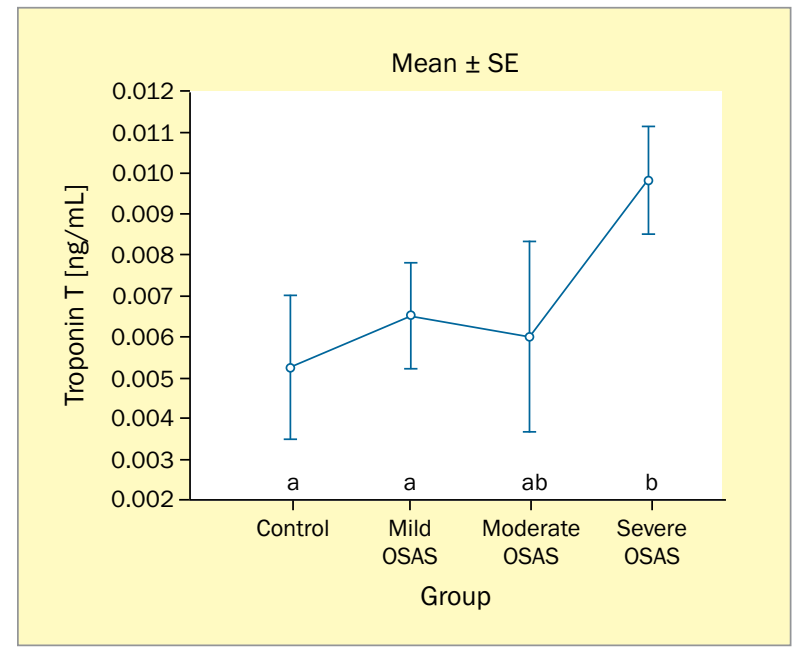

Figure 1. Troponin T concentration in patients with different grades of obstructive sleep apnea syndrome (OSAS) and in controls; SE - standard error 
Table 3. Correlation between troponin T concentration and polysomnographic indices

$\begin{array}{llcc}\text { Parameter } & & \text { Correlation coefficient } & p \\ & \mathrm{AHI} & 0.25 & 0.02 \\ & \mathrm{Al} & 0.21 & 0.04 \\ \text { Troponin T } & \mathrm{HI} & 0.25 & 0.02 \\ & \mathrm{RDT} & 0.25 & 0.02 \\ & \mathrm{RDTI} & 0.26 & 0.01 \\ & \text { Mean } \mathrm{SpO}_{2} & -0.11 & \mathrm{NS} \\ & \text { Minimum SpO } & 0.01 \\ & \text { t90 } & -0.26 & \mathrm{NS}\end{array}$

$\mathrm{AHI}$ - apnea-hypopnea index; $\mathrm{Al}$ - apnea index; $\mathrm{HI}$ - hypopnea index; RDT - respiratory distress time; $\mathrm{RDTI}$ - respiratory distress time index; $\mathrm{SpO}_{2}$ - saturation; $\mathrm{NS}$ - not significant

diseases [8]. In OSAS, cardiomyocyte damage can be related to inadequate amounts of oxygen as well as activation of the sympathetic system and results in the development of tachycardia and oxidative stress. The cardiomyocytes exposed to such conditions are damaged releasing troponins [9]. The literature data regarding the relationship between TnT and OSAS are inconsistent. Gami et al. have demonstrated that the severity of OSAS is associated with higher levels of TnT, hence subclinical myocardial damage, which leads to myocardial failure [10]. According to Randy [11], the severity of OSAS, measured with AHI, is correlated with increased TnT. However, multivariate analysis has not revealed the aforementioned correlation. In our study, multivariate analysis showed the influence of $\mathrm{AHI}$ and minimum nocturnal saturation on $\mathrm{TnT}$ levels. Likewise, the total time of apneas and hypopneas during the entire examination (RDT) was statistically significantly correlated with increased TnT levels. The above findings allow supposing that OSAS is one of the factors that can damage the myocardium. Interestingly, some study findings suggest that chronic hypoxia of cardiomyocytes is likely to lead to their degeneration and apoptosis; on the other hand, ischemic preconditioning of the myocardium is observed, which can reduce the extent and severity of infarction, thus have protective effects [12, 13]. The above phenomenon and its clinical implications have not been fully elucidated; therefore, further studies are required. Repeated episodes of nocturnal hypoxemia result in endothelial dysfunction and remodeling of vascular walls, thus can lead to the development of systemic and pulmonary hypertension [14]. Moreover, the degree of OSAS severity, defined by AHI, has been found to correlate with the condition of coronary endothelial vessels and to affect their decongestion [15]. Our study revealed that the degree of OSAS correlated with an increase in TnT. Higher levels of TnT were observed in the group with severe OSAS; in mild and moderate OSAS groups, the levels of TnT were lower. The above suggests that individuals with the most severe form of OSAS are at the highest risk of myocardial damage yet can also benefit most from appropriate treatment. Our findings are comparable with those of other authors dealing with the issue in question $[9,10,16]$. Therefore, the earliest possible identification of patients with OSAS risk factors is essential as it enables early diagnosis and prompt initiation of CPAP therapy [17]. The information on a correlation between OSAS and elevated levels of troponins can be clinically important for differential diagnosis. Based on them, effective prophylaxis can be provided and the influence of OSAS on the heart monitored [18]. Furthermore, such data can help to decide about invasive or conservative management in patients with non-specific thoracic pain complaints.

\section{Conclusions}

The relationship between sleep apnea syndrome and the level of serum TnT confirms that OSAS predisposes to myocardial damage in a manner dependent on the severity of sleep apnea. The increase in troponin level is mainly associated with $\mathrm{AHI}$ and minimum nocturnal saturation. This suggests that early treatment of OSAS patients may protect against myocardial injury.

\section{Conflict of interest(s)}

None declared. 


\section{Streszczenie}

Wstęp. Zespół obturacyjnego bezdechu sennego (OSAS) jest silnie związany z występowaniem powikłań sercowo-naczyniowych. W dalszym ciągu zależność między nasileniem tego schorzenia a stężeniem troponiny T (TnT) pozostaje niejasna.

Materiał i metody. Rozpoznanie i ocenę stopnia ciężkości OSAS oparto na nienadzorowanej, całonocnej, przesiewowej polisomnografii (PSG), wykonywanej bez nocy adaptacyjnej. Grupa badana liczyła 72 pacjentów z potwierdzonym OSAS ( w tym 31 chorych z łagodnym, 10 chorych z umiarkowanym oraz 31 pacjentów z ciężkim OSAS); grupa kontrolna liczyła 16 osób bez zaburzeń oddychania w czasie snu. Do PSG użyto aparatów spełniających kryteria urządzeń diagnostycznych klasy III według American Academy of Sleep Medicine.

Wyniki. Stwierdzono istotne statystycznie różnice pod względem stężeń TnT między chorymi z ciężkim OSAS w porównaniu z grupą kontrolną $(p=0,02)$ oraz osobami z łagodną postacią OSAS $(p=0,04)$. Wykazano, że czynnikami istotnie wpływającymi na stężenie TnT były wskaźnik oddech-spłycenie oddechu (AHI), wskaźnik oddechów (Al), wskaźnik spłyceń oddechu oraz minimalna nocna saturacja.

Wnioski. Zależność między OSAS i stężeniem TnT w surowicy potwierdza, że OSAS predysponuje do uszkodzenia mięśnia sercowego w sposób zależny od jego nasilenia. Wzrost stężenia TnT wiąże się przede wszystkim z AHI i minimalną nocną saturacją. Przedstawione wyniki wskazują, że wczesne leczenie pacjentów z OSAS może ich chronić przed uszkodzeniem mięśnia sercowego związanym z chorobą.

Słowa kluczowe: troponina T, obturacyjny bezdech senny, apnea-hypopnea index, uszkodzenie mięśnia sercowego, polisomnografia

Folia Cardiologica 2016; 11, 5: 372-376

\section{References}

1. Kiciński P., Zakrzewski M., Dybała A. et al. Obstructive sleep apnea - principles of diagnosis and treatment. Forum Med. Rodz. 2012; 6: 228-235.

2. Young T., Peppard P., Gottlieb D. Epidemiology of obstructive sleep apnea. A population health perspective. Am. J. Respir. Crit. Care Med. 2002; 165: 1217-1239.

3. Shochat T., Pillar G. Sleep apnoea in the older adult: pathophysiology, epidemiology, consequences and management. Drugs Aging 2003; 20: 551-560.

4. Sleep-related breathing disorders in adults: recommendations for syndrome definition and measurement techniques in clinical research. The Report of an American Academy of Sleep Medicine Task Force. Sleep 1999; 22: 667-668.

5. Yilmaz F., Ozyildirim S., Talay F. et al. Obturacyjny bezdech senny jako czynnik ryzyka rozwoju chorób układu sercowo-naczyniowego. Folia Cardiol. 2008; 3:74-78.

6. Al-Otaiby M.A., Al-Amri H.S., Al-Moghairi A.M. The clinical significance of cardiac troponins in medical practice. J. Saudi Heart Assoc. 2011; 23: 3-11.

7. Bradley T.D., Floras J.S. Obstructive sleep apnea and its cardiovascular consequences. Lancet 2009; 373: 82-93.

8. Shivalkar B., van de Heyning C., Kerremans M. et al. Obstructive sleep apnea syndrome: more insights on structural and functional cardiac alterations, and the effects of treatment with continuous positive airway pressure. J. Am. Coll. Cardiol. 2006; 47: 1433-1439.

9. Han Q., Yeung S.C., M. Ip. M.S., Mak J.C. Cellular mechanisms in intermittent hypoxia-induced cardiac damage in vivo. J. Physiol. Biochem. 2014; 70: 201-213.
10. Gami A.S., Svatikova R., Wolk R. et al. Cardiac troponin T in obstructive sleep apnea. Chest 2004; 125: 2097-2100.

11. Randby A., Namtvedt S.K., Einvik G. et al. Obstructive sleep apnea is associated with increased high-sensitivity cardiac troponin T levels. Chest 2012; 142: 639-646.

12. Shah N.A., Yaggi H.K., Concato J., Mohsenin V. Obstructive sleep apnea as a risk factor for coronary events or cardiovascular death. Sleep Breath. 2010; 14: 131-136.

13. Shah N., Redline S., Klar Yaggi H. et al. Obstructive sleep apnea and acute myocardial infarction severity: ischemic preconditioning? Sleep Breath. 2013; 17: 819-826.

14. Sajkov D., McEvoy R.D. Obstructive sleep apnea and pulmonary hypertension. Prog. Cardiovasc. Dis. 2009; 51: 363-370.

15. Kadohira T., Kobayashi Y., Iwata Y. et al. Coronary artery endothelial dysfunction associated with sleep apnea. Angiology 2011; 62: 397-400.

16. Demir N., Köktürk O., Ciftçi T.U. et al. The association of troponin I levels with severity of obstructive sleep apnea syndrome. J. Sleep Disord. Ther. 2012; 1: 105.

17. Peled N., Abinader E.G., Pillar G. et al. Nocturnal ischemic events in patients with obstructive sleep apnea syndrome and ischemic heart disease: effects of continuous positive air pressure treatment. J. Am. Coll. Cardiol. 1999; 34: 1744-1749.

18. Berner J., Lelonek M. Bezdech senny jako czynnik ryzyka u pacjentów z chorobą wieńcową. Folia Cardiol. 2014; 9: 57-163. 